\title{
LEGITIMACY SIGNALS AND FAMILY IPO PERFORMANCES
}

\author{
Hung-bin Ding ${ }^{1}$, Kuntara Pukthuanthong ${ }^{2}$ \\ ${ }^{1}$ Department of Management and International Business, Loyola University, \\ Maryland, 4501 N. Charles St., Baltimore, MD 21210 \\ ${ }^{2}$ Department of Finance, San Diego State University, San Diego, CA 92182-8230 \\ E-mails: ${ }^{1}$ hding@loyola.edu (corresponding author); ${ }^{2}$ kpukthua@mail.sdsu.edu
}

Received 24 October 2011; accepted 09 July 2012

\begin{abstract}
The objective of this research is to examine the relationship between signals including governance and management practices and the performance of family firms IPOs. Using IPO data of 129 family firms and 129 comparable non-family firms from the Taiwan Stock Exchange, our findings highlighted the role of non-family insiders, or non-family affiliated directors in the IPOs of family firms. Our comparison between family and non-family IPOs shows hiring prestigious underwriters significantly improves the performance of family firm IPOs. Finally, we found the industries of IPO firms moderate the relationship between corporate governance characteristics and IPO performances, as non-family firms in technology industries are perceived to be more legitimate than their family counterparts. This paper makes three contributions to existing research. Firstly, we contribute to the legitimacy theory by suggesting an interaction effect between internal (organizational) and external (environmental) factors. Secondly, our analysis highlighted the roles of affiliated directors and industry in the performances of public family firms. Thirdly, this study contributes to the family business research by underscoring the differences between family and non-family firms in the IPO context.
\end{abstract}

Keywords: legitimacy, signaling, family ownership, family firms, Taiwan, initial public offering.

Reference to this paper should be made as follows: Ding, H.; Pukthuanthong, K. 2013. Legitimacy signals and family IPO performances, Journal of Business Economics and Management 14(1): 156-181.

JEL Classification: G30, L26, M10.

\section{Introduction}

Family firms are business organizations managed or controlled by one or more families. This structure minimizes the principal-agent problem highlighted in Jensen and Meckling (1976). However public family firms, like other public corporations, need to attend to shareholder value and investors' perceptions by demonstrating their "fitness to financial markets" (Davis 2005), because the integration of ownership and management gives the family owners great power to reap private benefits from the firm by expropriating minority shareholders (La Porta et al. 2000). Family firms fail to demonstrate its 
market fitness would lose their legitimacy and suffer from equity undervaluation, which makes the family owner vulnerable to lose control of its business.

Legitimacy is the external stakeholders' perception about how well an organization meets expectations (Singh et al. 1986; Suchman 1995). This perception plays a central role in investors' evaluation of equity quality (Zuckerman 1999, 2000; Sun, Tobin 2005; Bell et al. 2008). Establishing social acceptance or legitimacy in the capital market is a challenging task for a family firm offering its equities to the public for the first time. Because the initial public offering (IPO) firms are relatively unknown to investors (Rao 1994; Rao, Chandy, Prabhu 2008), potential investors have limited means to examine the track record of the IPO firms but to rely on information from the prospectuses. This accentuates the importance of signaling (Shapiro 1983). Many empirical analyses have confirmed the positive impacts of select corporate governance and management practices in IPO signaling, including but not limited to board independence, post-IPO shares retaining, and underwriter reputation (Burton et al. 2004). Effective signals addresses investor's concerns associated with the idiosyncratic organizational (internal) and environmental (external) conditions of firms and therefore the contents and effects of signaling can be different from one organization to another (Zajac, Westphal 1994; Ward et al. 2009).

In the IPO market, board independence and share retaining are examples of universally desirable governance signals to potential investors. However, in addition to the insider and outsider directors frequently analyzed in governance studies, the non-family executive directors constitute a third category of board of directors. For the sake of convenience, we label these individuals as "affiliated directors." They are professional managers, corporate insiders, very often friends of the controlling family, and even business partners. But these managers are often considered "not part of family" to the family owners (Esteban et al. 2011) ${ }^{1}$. Although non-family managers play an important role in professionalizing family firms and are instrumental to the long-term success of family firms (Schulze et al. 2001), there has been little discussion about principal-principal agency problem and IPO performance implication of these non-family affiliated directors.

On the account of external conditions, we propose that industry as an external moderating factor between organizational policies such as governance and management practices and their relationship with IPO performance. Family firms and non-family firms have different behavioral patterns because the former group's governance and management decisions need to incorporate the interest of family (Habbershon et al. 2003). The behavioral uniqueness may be more acceptable or even desirable in some industries but may be less desirable in other industries. For example, a strong family identity usually enhances the performances of family firms in service industries (Craig et al. 2008). The extant literature shows the public generally perceives that family firms are different from non-family firms. However, the impact of such a perceptive differential on the equity market performance is largely unknown.

\footnotetext{
${ }^{1}$ All of the affiliated directors in our sample are employees.
} 
This research suggests that a family firm can improve its IPO performance using governance practices and managerial decisions as signals. While some of these signals are universally accepted and expected by investors, others are unique to family firms. A family firm IPO meeting these expectations enjoys better IPO performances, measured by underpricing - the difference between the offer price and the closing price of an IPO. We examine the effects of signaling in legitimacy building by testing the impacts of select governance and management signals on underpricing. Our analysis on family firm IPO makes three contributions to the existing research. Firstly, we contribute to the legitimacy theory by suggesting an interaction effect between organizational (internal) and environmental (external) factors. Secondly, our analysis highlights the roles of affiliated directors and the industry in the performances of public family firms. Thirdly, this study contributes to the family business research by underscoring the differences between family and non-family firms in the IPO context. We proceed as follows. First, we review the relevant literature and present hypotheses. Next, we describe the methodology and report our analytical results. We conclude with a discussion of our research implications for research on corporate governance, family business and IPO research.

\section{Legitimacy and signaling}

Legitimacy of a business is determined by how well this organization is accepted by its investors. This social acceptance is an organization's "precondition to compete" (Pfeffer, Salancik 1978) or "license to operate" in the market (Chiu, Sharfman 2011). In the capital market, investors reward the legitimate family firms by paying premium prices to acquire equities of these organizations (Sun, Tobin 2005; Bell et al. 2008; Bédard et al. 2008), because investors would take an 'illegitimacy discount' in the valuation of equities offered by firms with lower legitimacy (Zuckerman 1999, 2000).

When the market is perfectly efficient, investors would have sufficient information to assess the businesses. Therefore, better businesses enjoy better social acceptance or legitimacy. Nevertheless, when the market is not perfectly efficient, good family businesses will be motivated to signal investors to establish better legitimacy against inferior family businesses. According to Spence's signaling theory $(1973,2002)$, inferior actors in any market has little incentive to invest in signaling to stand out in competition. As investors have little information to differentiate high quality to lesser quality equities, all of the competing equities will be treated similarly. In short, lesser quality firms are free riding. However, good quality firms would be very motivated to stand out among peers because investors are willing to pay premium prices for equities issued by quality firms. Considering legitimacy as a quality indication, the family firms whose business fits investors mental model of good businesses will be able to enjoy higher legitimacy than other family firms in the capital market. In the context of family firms IPO, good family firms can differentiate from lesser quality family firms through signaling (Leland, Pye 1977).

Despite IPO issuer's efforts to produce positive signals with good governance mechanisms, the processing and interpretation of these signals is a subjective process. When 
an investor contemplates the legitimacy of a firm, he/she creates an image of an organization then applying behaviors and traits of this organization to the social norms embedded in this socially constructed image to see if these behaviors and traits of the focal firm are in agreement with the norms (DiMaggio 1991). In the context of IPO, a norm can be viewed as investors' general idea about what a good IPO firm "should do". These expectations form a mental model of a legitimate IPO firm. An IPO issuer not fitting this mental mold creates uncertainty in the valuation of the equity and may be rejected or under-valued by the potential investors.

Empirical studies have confirmed the positive effects of signaling in IPO (Leland, Pye 1977; Beatty, Ritter 1986; Filatotchev, Bishop 2002). These findings generally support the notion that IPO firms with better growth potential can communicate with their potential investors by clearly articulating their superior quality to investors in various channels of disclosures such as SEC filings, news releases, and road shows. For example, firms reporting above average financial performances are more likely to enjoy growth in stock prices because good financial performances improve corporate reputation (Fombrun, Shanley 1990; Shrivastava et al. 1997). However, it is not too difficult for lesser quality IPO issuers to prepare nice presentations using the same channels of communication to blur the distinction between high quality and low quality IPOs. Therefore, many IPO firms have adopted select governance and management practices to win acceptance from their potential investors (Daily et al. 2003) as the practices are more difficult and costly for lesser quality IPOs to imitate. Examples of these signals include organizational commitment to social responsibilities (Fombrun, Gardberg, Barnett 2000), high institutional ownership (Fombrun, Shanley 1990), and organizational downsizing (Lee 1997). In addition, changing the name of a company to DotCom implies a major strategic switch to a high risk, high growth business model (Lee 2001). In summary, governance and management practices can be used as signals for an IPO firm to establish social acceptance (i.e. legitimacy) among its investors.

\section{Family firm IPO performance}

The active participation of management by family shareholders has profound influence to the behaviors and value of these firms (Litz 2008). Family business literature has constantly found that family firms are long-term oriented and are more conservative than non-family firms (Westhead, Howorth 2006; Naldi et al. 2007; Litz 2008). Such behavioral traits reflect the family owners' propensity to maintain the legacy of their families and to create a source of long-term, stable family income (Naldi et al. 2007). In order to control the firm, the family owners can adopt a number of control mechanisms including pyramid ownership, voting agreement to pool family shareholders, board overrepresentation, and dual-class stocks (Villalonga, Amit 2006). Without sufficient checks and balances of family owners' power in the corporate board, minority shareholders have limited means to prevent potential expropriation.

Building on the signaling theory and legitimacy theory, we argue that a good family firm in the IPO market would be motivated to differentiate itself from others through signaling. One of the major governance mechanisms to manage this principal-principal 
problem is the composition of the corporate board. The appointment of independent directors, who are not affiliated with the firm or a member of the family, on the corporate board improves the oversight and reduces the information asymmetry between majority and minority shareholders in public family firms (Anderson, Reeb 2004). High percentage of independent directors on the board also increases the overall performance of the family firms (Anderson, Reeb 2004; Anderson, Mansi, Reeb 2004) as these outsiders bring in needed new resources and knowledge to manage the family firm (Anderson, Reeb 2004). In many cases, IPO firms recruit highly experienced and respected individuals to serve on their boards. The appointment of these highly qualified directors also represents a symbolic action of good governance to secure investor confidence and acceptance (Jenkinson, Ljungqvist 2002; Certo 2003; Li, Naughton 2007; Shekhar, Stapledon 2007).

As establishing sufficient shareholder protection is essential when a firm offers equities through the IPO process (Baker, Gompers 2003; Shekhar, Stapledon 2007), board independence signals to the potential investors that there are adequate protections of minority shareholder interests and/or the company is under control by highly qualified individuals (Luan, Tang 2007). Given the dominant influence of family shareholders in family firms, the appointment of outside, non-family board members is particularly significant to the protection of minority shareholders' interests. This practice is in line with investors' perception of good governance practice and can enhance the acceptance, legitimacy, of the family firm. Therefore, we hypothesize:

H1: High percentage of outside non-family directors on the corporate board improves the IPO performance of a family firm.

While the outside independent directors are generally considered as a governance mechanism to improve the effectiveness of monitoring, the role of non-family executive directors in the board of directors is more complicated. Non-family executives are corporate insiders. As employees of the family firms, the appointments of these affiliated directors on the corporate board can be the family owners' tactic to control the board through a dominant coalition to control the family business after IPO. Because of such affiliation, the conventional view of board independence suggests that these affiliated directors are less effective in safeguarding the interests of non-family shareholders than external, independent directors (Anderson, Reeb 2004). The appointment of affiliated directors reduces the effectiveness of the corporate board. Therefore, the percentage of affiliated directors on the board is likely to be positively correlated with the underpricing of a family firm IPO.

However, unlike external, independent directors, working for the same company provides a platform of communication and collaboration for the affiliated directors to effectively fulfill their director duties. Several studies have suggested that the lack of organizational knowledge and time hinders the effectiveness of corporate boards (Kim, Cannella 2008; Payne et al. 2009; Conger, Lawler 2009). The ineffectiveness of the board is likely to have negative impact on the investors' acceptance. We argue that the inclusion of non-family, affiliated directors could mitigate the knowledge and time problems. Firstly, affiliated directors are professional managers and often long-term employ- 
ees. They possess good knowledge about their organizations, including the institutional norms, power dynamics, organizational culture, core values, product, and market. Their knowledge also makes them expert directors (McDonald, Westphal, Graebner 2008) who are able to assist other less knowledgeable board members. In addition, the superior knowledge of corporate insiders enables them to better influence the strategic decisions of the firm (Bathala, Rao 1995). Secondly, since board members as a group spends relatively little time together, corporate insiders' affiliation with the firm allows them to work effectively between meetings on issues that concern the board. For example, an affiliated director who is appointed for his/her expertise in technology can assist the board to be more informed about the marketing strategy and challenges of the firm by talking to colleagues in the marketing departments between board meetings.

Since the appointment of affiliated directors weakens protection of minority shareholder interests in the board of family firms, there should be a negative correlation between board effectiveness and the influence of affiliated directors on the board. However, the non-family, affiliated directors also improve the team effectiveness of the board when a significant percentage of directorship is occupied by these corporate insiders. Therefore the board of directors is most effective when there is high or low percentage of affiliated directors on the board; least effective when their numbers are not enough to improve the team effectiveness.

H1a: There is a curve relationship between the percentage of non-family affiliated directors in corporate board and performance of a family firm IPO. This curve will appear to be an inverse U-shape using underpricing as the measure of IPO performance.

Share retention is another influential signal to attain legitimacy. As high percentage of share retaining is more likely to bond the family wealth to the future performance of the firm, the percentage of shares retained by the owners becomes an indication of owners' commitment to their firms after IPO (Leland, Pyle 1977; Certo et al. 2001). The more the post-IPO shareholding, the higher the cost imposed on owners from the decline of firm value (Jensen, Meckling 1976). A higher percentage of family share ownership at IPO suggests an alignment of interests between family owners and the investors (Bruton, Chahine, Filatochev 2009; Chahine, Tohmé 2009), mitigating the principalprincipal agency problem. Since family firm owners have more information about the true value and potential of their companies than investors, family owners' willingness to retain large percentage of shares at IPO signals their confidence in the future prospect of the firm (Leland, Pyle 1977; Downes, Heinkel 1982; Clarkson et al. 1991). In short, family insiders' retained equity at IPO is an indication of original shareholders' level of confidence to their own companies. Such confidence helps reduce aftermarket investors' uncertainty (Certo et al. 2001), while increasing investor acceptance. We therefore predict the following:

H2: The higher the percentage of shares retained by family owners at IPO, the better the family firm IPO performance. 
In addition to the characteristics of the board and ownership, underwriter reputation is also a major factor in attaining investors' acceptance. Underwriters are investment bankers hired by IPO firms to promote and sell the offering equities. They assist issuers to satisfy legal requirements of IPO by closely monitoring issuers' pre-IPO and postIPO activities. Low quality works in IPO preparation would tarnish the reputation of underwriters. However, some underwriters are more capable than others in identifying the fair price of IPO stocks by, for example, uncovering hidden assets or other variable factors in the issuer. These more capable investment bankers enjoy higher prestige than their peers in the underwriting industry. Partnering with these high prestige underwriters sends a positive signal about the quality of the firm to the market (Beatty, Ritter 1986). The benefits derived from hiring prestigious underwriters could be particularly evident in family firm IPOs for several reasons. Firstly, equity pricing is always a challenging task. However, pricing the equities of a family firm may be more difficult because of the complexities associated with the managerial and governing involvement of multiple family members in the firm. Secondly, while many view a privately-owned family firm as a family legacy, the family owners' commitment to the firm may be different after their shares are diluted through the IPO process. Thirdly, the family owners' intent to pass the business to a younger family member may have significant impact on the value of the firm. Fourthly, since family firms are far less transparent than other public firms (Anderson, Duru, Reeb 2009), pricing family IPOs is more challenging. As prestigious investment bankers are more capable of resolving information asymmetries between issuers and investors than others (Carter, Manaster 1990; Carter, Dark, Singh 1998), hiring prestigious underwriters certifies the information disclosed by the IPO issuers in the prospectus and other means of investor communications.

In summary, hiring a prestigious underwriter may have a stronger effect in reducing family firm IPO uncertainty than in non-family IPOs, suggesting a stronger positive impact on legitimacy improvement in family firm IPO $s$ than in non-family firm IPOs.

H3: Prestigious underwriters improve the performance of both family and non-family firm IPOs. This effect is greater in family firms.

In addition to management and governance practices, an IPO firm's choice of industry can also be a key factor in how well an IPO firm fits investors' mental model. A firm will have greater difficulty to attain social acceptance from potential investors' if it operates in multiple industries. According to Zuckerman (2000), diversified corporation can be perceived as less legitimate than another firm concentrating its operations in one industry because investors have greater difficulty to compare them to a standardized mental model for the former. Similarly, it will not be easy to establish legitimacy if a firm's behaviors are unique to its peers in the same industry. In both situations, the "difficulty to evaluate" reduces the legitimacy of a firm.

Family firms are common in many industries, but they are much less prevalent in technology industries. The MassMutual American Family Business Survey (2002) reports that more than $64 \%$ of survey respondents operate in the manufacturing, wholesale, 
and retail industries. Other industries represented in this survey, including agriculture/ forestry, financial services, high technology/biotechnology, mining/oil and gas, real estate, telecommunications and transportation, account for about $35 \%$ of survey participants. Despite strong emphasis on the growth in profit (The MassMutual American Family Business Survey 2002), most family firms have little growth opportunities or are reluctant to face the challenges of fast growth organizations (Erven 1998). Although venerable family firms such as Corning Inc. have made extensive efforts to develop and perfect high risk, high reward technologies, the results of the MassMutual survey is in agreement with the findings of previous studies which profile family firms as risk averse, long-term oriented organizations (Gómez-Mejía et al. 2007). The image of family firms is found to be more compatible to service industries than other industries (Craig et al. 2008).

On the other hand, technology-based industries are often characterized as high risk and high reward (Coates 2005). High performing innovative firms in technology industries tend to encourage their employees to take risk (Hitt, Hoskisson, Ireland 1990). Since family firms and technology-based firms have very different organizational traits, investors who are interested in investing a technology-based family firm would find two conflicting organizational traits co-existing in these organizations. Such inconsistency decreases the legitimacy of family firms as a technology firm. Therefore we hypothesize that the IPO firms operating in the technology industry has a moderating effect in the relation between the governance signals of family firms and their IPO performances:

H4: Except hypothesis H1a, the relationships hypothesized in H1 3 are weaker when the family firm operates in the technology-based industries.

\section{Sample selection}

We tested our hypotheses using Taiwanese public firms, because public companies in Taiwan are mandated by law to disclose the family relationship among member of top management team, corporate board, and major shareholders, which is defined as individuals or institutions holding more than 5\% shares OR the top ten largest shareholders of a firm (Financial Supervisory Commission 2007). With this exception, the disclosure requirement for initial public offerings in Taiwan is similar to that of the SEC filing requirement in the United States. The electronic forms of these disclosures are accessible to the public from the Market Information Post System maintained by the Taiwan Stock Exchange Corporation.

In this research, we identify family firms following the two similar criteria adopted by Anderson and Reeb (2003), and Villalonga and Amit (2006). Firstly, a firm is controlled by the members of the founding family, which includes the decedents of the original founders. Secondly, a family is in control of a family firm when two or more members of the family serve on the board or the top management team. On average, family members in our family firm sample occupy $29 \%$ of the board membership. We identified 
$129^{2}$ family firms profiled in the 2005 Business Groups in Taiwan (published in 2006). This publication profiles the largest 250 Taiwan-based business groups in terms of total assets on an annual basis. Our emphasis on larger organizations was similar to previous research focusing on family firms indexed by the S\&P 500 (Anderson, Reeb 2003; Villalonga, Amit 2006). The 129 family firms we identified went public between 1962 and 2005 in the Taiwan Stock Exchange. We were able to obtain the IPO characteristics data of these family firms from the Securities Data Corporation's (SDC) Global New Issues database. Post-IPO stock prices were collected from the Datastream and we compared them with those provided in the SDC. We collected cash and equivalents from both the SDC and the Worldscope. Firm age was the difference between founded and IPO dates, which we collected from the SDC and company's website. The corporate governance data was obtained from Taiwan Economic Journal (TEJ).

Our close examination of the SDC database revealed several data problems. We found errors in IPO issue dates for the majority of our sample. For example, the SDC often mistakenly provided announcement or subscription dates as issue dates. Over 50 percent of IPOs in Taiwan have this problem. To overcome this data problem, we manually cross-referenced each of our sample IPOs with Bloomberg to identify and correct the erroneous issue dates.

\section{Non-family matching firms}

We also created a list of 129 non-family Taiwanese firms. Following the process developed by Kim and Ritter (1999), and Purnanandam and Swaminathan (2004), we identified a matching non-family firm for each family firm in our sample with comparable IPO date, size, and liquidity as IPOs in the most recent fiscal year. Total offer value captures size and cash per sales captures liquidity. The first-day IPO market capitalization was not used in matching because it would not be available to an investor or underwriter before the offering date. To choose a particular matching firm, we first explored the Taiwanese IPO data in SDC and stock prices in Datastream. We identified non-family firms sharing the same four-digit SIC code as its family firm counterpart and then shortened the list by excluding firms that did not go public within one year of the IPO date of comparable family firm ${ }^{3}$. Setting a limit to the date of IPO allowed us to estimate the IPO performance of non-family firms under similar market conditions. From these firms, REITs, closed-end funds, ADRs, and firms with share prices less than five dollars were excluded. This screening criterion was normally used in the extant IPO literature. We then searched for firms whose total offer value is between $75 \%$ and $125 \%$

\footnotetext{
2 Among 129 family IPOs, one of them went public in 1962, 1 in 1964, 2 in 1972, 3 in 1973, 2 in 1976, 1 in 1977, 1 in 1983, 2 in 1987, 4 in 1988, 3 in 1989, 3 in 1990, 6 in 1991, 9 in 1992, 5 in 1993, 8 in 1994, 5 in 1995, 9 in 1996, 6 in 1997, 10 in 1998, 9 in 1999, 10 in 2000, 6 in 2001, 16 in 2002, 2 in 2003, 4 in 2004, and 1 IPO in 2005.

${ }^{3}$ When we select matching non-family firms that went public within 3 years before the IPO, the results remain intact. We choose to apply a window of 1 year since the window of 3 years is somewhat long for comparable non-family IPO firm and many things can happen to market sentiment in three years.
} 
of the family IPO's total offer value. If we had more than one firm left on the list of potential candidates, we chose the one whose cash per sales was closest to the family firm in the most recent fiscal year. If there was no qualified candidate, we relaxed the criteria to widen our search. Each family IPO got a unique non-family matching firm from the same industry.

\section{Dependent variable}

Our dependent variable is IPO underpricing measured as the market-adjusted percentage return from the offer price to the closing price on the fifteenth calendar day after the IPO (see e.g., Loughran, Ritter, Rydqvist 1994; Ljungqvist, Jenkinson, Wilhelm 2003; Ritter 2003).We apply longer windows is because the price movements in the Taiwanese market during the initial days of trading are restricted by exchange regulation ${ }^{4}$.The price of an IPO stock could continue to hit the limit several days after the IPO date as the equilibrium price of the stock is delayed by regulation. Computing IPO underpricing using the first closing price ignores any adjustments in the market value of the IPO shares after the "non-hit" price is observed.

\section{Independent variables}

The Percentage of outside directors is defined as number of directors who are neither the members of controlling family nor the management team per total number of directors. For non-family firms, it is defined as the number of directors who are not members of management team per total number of directors. The Percentage of affiliated directors captures the influence of affiliated directors on the board. Because the size of corporate board varies, the absolute number of affiliated directors is not a very reliable indication of non-family director influence. Therefore, we obtained the value of this variable by dividing the number of affiliated directors by the total number of directors. The Percentage of affiliated directors ${ }^{2}$ estimates a curvilinear relationship between IPO underpricing and the percentage of affiliated directors on the corporate board. The Percentage of family ownership at IPO is measured as the percentage of shares owned by original family owners before the first trading date. The Percentage of insider ownership at the IPO is the percentage of total shares owned by insiders of non-family IPOs. Lastly, following Megginson and Weiss (1991), we gauge Underwriter ranking using the average market share of the underwriter. Detail definitions of each variable are presented in the Appendix.

\section{Control variables}

We draw on the extant IPO literature to include seven firm-level underpricing determinants including IPO volume, Technology dummy, Log of proceeds, Firm age, Cash per sales, Potential successor, Year fixed effect.

\footnotetext{
${ }^{4}$ This argument also applies to France and Japan where "circuit breakers" are installed to limit postIPO daily price fluctuations within a certain preset limit.
} 


\section{Descriptive statistics}

Table 1 provides mean and median among all variables for family and non-family IPOs. We also provided p-value of t-statistics (Wilcoxon signed rank test) of mean (median) differences. Table 2 presents Pearson correlation coefficients among variables for family and non-family IPOs. The results of correlation coefficients do not show a sign of multicollinearity problem. None of the variance inflation factor (VIF) statistics estimated in conjunction with our models exceeds 10 , which is an indication of multicollinearity (Kutner, Nachsheim, Neter 2004).

Table 1. Descriptive statistics of IPO underpricing

There are 129 family and 129 non-family Taiwanese IPOs. Family IPOs went public during January 1, 1962 and December 31, 2005. The matching firm is a non-family firm that was in the same industry, went public within one year of the family IPO, and had comparable total offer value and cash per sales in its most recent fiscal year. All variables are described in the Appendix. White's heteroskedasticity-adjusted t-statistic provides a test for the difference in means and the Wilcoxon Signed Rank test provides a test for the difference in medians.

\begin{tabular}{|c|c|c|c|c|c|c|}
\hline \multirow{2}{*}{ Variables } & \multicolumn{2}{|c|}{$\begin{array}{l}\text { Family-controlled } \\
\text { IPOs }\end{array}$} & \multicolumn{2}{|c|}{$\begin{array}{c}\text { Non-family controlled } \\
\text { IPOs }\end{array}$} & \multicolumn{2}{|c|}{ Difference } \\
\hline & Mean & Median & Mean & Median & $\begin{array}{c}\text { T-stat } \\
\text { (P-value) }\end{array}$ & $\begin{array}{l}\text { Wilcoxon-Test } \\
\text { (P-value) }\end{array}$ \\
\hline $\begin{array}{l}\text { 15-day underpricing } \\
(\%)\end{array}$ & 19.85 & 13.22 & 28.27 & 16.85 & 0.123 & 0.112 \\
\hline $\begin{array}{l}\% \text { of outside non- } \\
\text { family directors }\end{array}$ & 53.14 & 51.12 & 72.15 & 89.21 & 0.000 & 0.000 \\
\hline $\begin{array}{l}\% \text { of affiliated } \\
\text { directors }\end{array}$ & 25.92 & 25.78 & NA & NA & & \\
\hline $\begin{array}{l}\% \text { of family } \\
\text { ownership at IPO }\end{array}$ & 8.39 & 17.04 & NA & NA & & \\
\hline $\begin{array}{l}\% \text { of insider } \\
\text { ownership at IPO }\end{array}$ & NA & NA & 6.49 & 3.22 & & \\
\hline Underwriter ranking & 3.91 & 3.71 & 3.38 & 4.98 & 0.131 & 0.090 \\
\hline IPO volume & 38.67 & 38.41 & 46.82 & 46.93 & 0.347 & 0.309 \\
\hline $\begin{array}{l}\text { Technology dummy } \\
(\%)\end{array}$ & 30.74 & 29.95 & 20.47 & 16.22 & 0.095 & 0.089 \\
\hline Log of proceeds & 14.51 & 15.93 & 18.46 & 17.51 & 0.189 & 0.455 \\
\hline Firm age (years) & 7.16 & 2.12 & 1.23 & 0.24 & 0.004 & 0.009 \\
\hline Cash per sales (\%) & 40.22 & 3.76 & 25.68 & 1.04 & 0.008 & 0.064 \\
\hline $\begin{array}{l}\text { Potential successor } \\
\text { dummy }(\%)\end{array}$ & 16.49 & 13.22 & NA & NA & & \\
\hline Number of IPOs & & & & & & \\
\hline
\end{tabular}




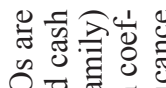

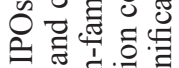
$\lambda \cong$

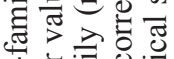

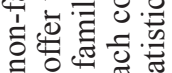
푱ㅇㅇ

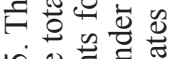
ชิ응 踏晋 的卷

क ఏ है

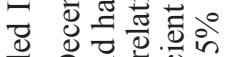

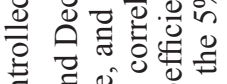

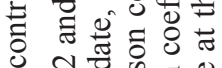

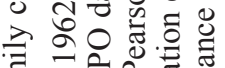
馬

言

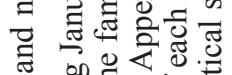

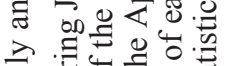
交

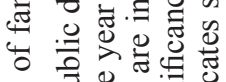

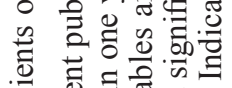

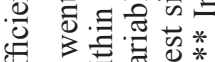

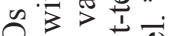

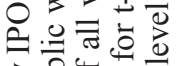
하을 政

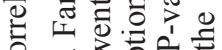
8 is 3 ن

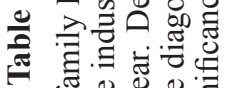
政 을 它然

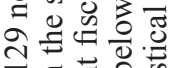
. : 등 可㖷 은 굴

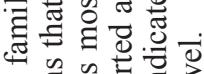
은

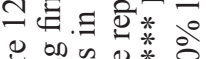
空.

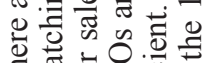

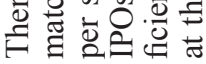

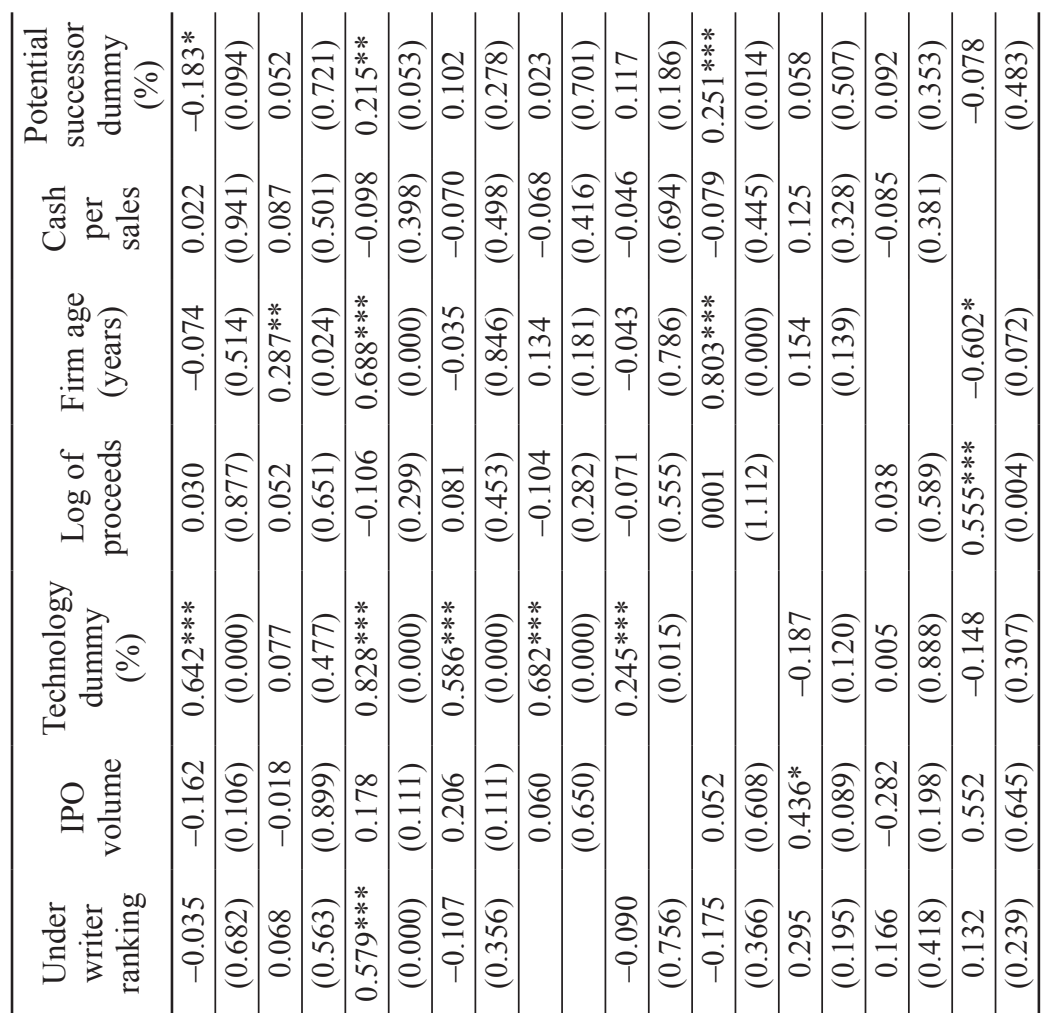

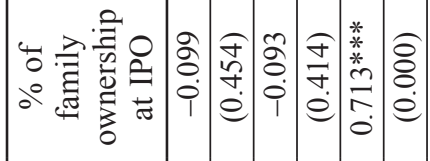

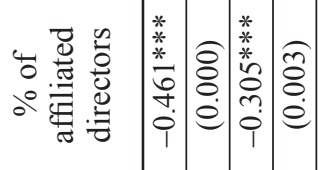
竞:

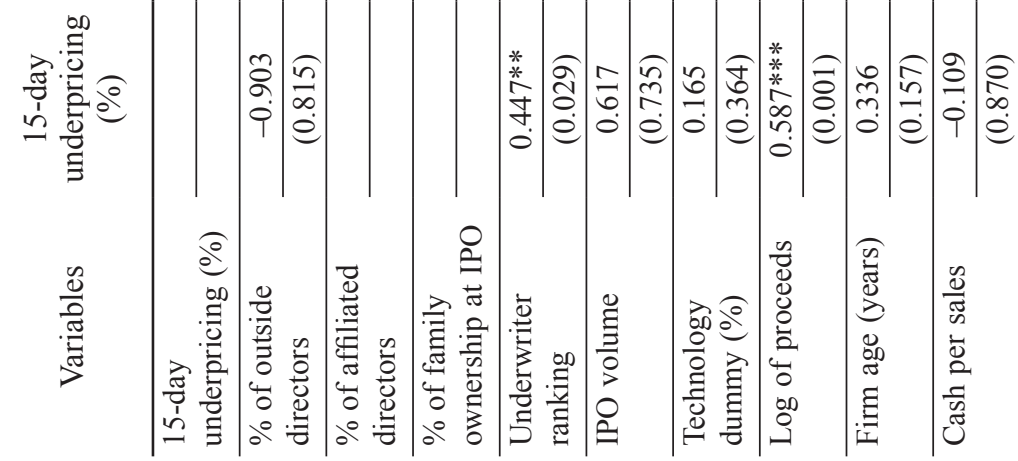




\section{Results of analysis}

Table 3 illustrates regression results of underpricing on various IPO and family ownership variables. Having outsider on board significantly reduces underpricing for 15-day returns of family and non-family firms. The effect is much higher for family firms; one percent increase in outside non-family directors reduces underpricing by $1.18 \%$ for family firms but only $0.44 \%$ for non-family firms. The difference in the effect of outside directors on underpricing between family and non-family firms is highly significant with p-value of 0.002 . This result supports our first hypothesis.

In addition, the percentage of affiliated directors increases underpricing. Our analysis shows a negative and significant relationship between underpricing and the percentage of affiliated directors ${ }^{5}$ thereby suggesting, as number of affiliated directors surpasses a certain level, the relation between underpricing and percentage of affiliated directors becomes negative. Taken together, the percentage of affiliated directors has an inverse U-shape relationship with underpricing supporting our hypothesis 1a. The expected percentage of family ownership at IPO is negatively related to 15-day underpricing. IPOs that have high level of family ownership at the IPO indicate original shareholder's confidence in or commitment to the firm. Such confidence lowers the amount of market uncertainty and thus underpricing. This result supports our second hypothesis. As a comparison, we include percentage of insider ownership in non-family regression but its coefficient is not significant. As such, insider ownership for non-family firms does not indicate the same kind of commitment as for family firms.

Finally, while partnering with prestigious underwriters reduces the extent of underpricing in family IPOs, partnering with highly ranked underwriter significantly increases the underpricing of non-family firms. The difference of underwriter ranking coefficients between family and non-family firms is significant at $1 \%$ with $p$-value of 0.002 . This result supports the third hypothesis that underwriter reputation has a stronger impact on the reduction of family firm IPOs than on the non-family firm IPOs.

Overall, percentage of outside non-family director, affiliated directors, family ownership at the IPO, age, and cash per sales decrease underpricing whereas underwriter ranking and technology industry increases the family firms underpricing. For non-family firms, the percentage of outside directors and IPO proceeds decrease their underpricing while underwriter ranking and high-tech industry increase their underpricings ${ }^{6}$.

\footnotetext{
${ }^{5}$ We performed a battery of sensitivity analyses to check the robustness of our findings. The results are available upon request.

${ }^{6}$ In addition, we conduct robust checks and a series of sensitivity analyses to ensure that there is no multicollinearity and that the correct functional form was chosen (i.e., there is no redundant and/ or omitted variables). The results are quantitatively similar to the main results and available upon request.
} 
Table 3. Determinants of IPO underpricing

This table presents regressions of 15-day underpricing of 129 family and 129 non-family IPOs. Family IPOs went public from January 1, 1962 to December 31, 2005. The non-family IPOs are matching firms that went public within one year of the family's IPO date, and had comparable total offer value and cash per sales in its most recent fiscal year. Descriptions of all variables are in the Appendix. White's heteroscedasticity-adjusted t-statistic is shown under each coefficient. $\mathrm{P}$ (Diff) is the $\mathrm{p}$-value from a t-test for the difference between corresponding coefficients of family and non-family firms. *** Indicates statistical significance at the $1 \%$ level. ** Indicates statistical significance at the 5\% level. * Indicates statistical significance at the $10 \%$ level.

\begin{tabular}{|c|c|c|c|}
\hline \multirow{2}{*}{$\begin{array}{c}\text { Explanatory } \\
\text { variables }\end{array}$} & \multicolumn{3}{|c|}{ 15-day underpricing } \\
\hline & Family & Non-family & $\mathrm{P}$ (Diff) \\
\hline Constant & $\begin{array}{c}20.849 * \\
(1.966)\end{array}$ & $\begin{array}{l}28.737 \\
(0.379)\end{array}$ & 0.005 \\
\hline$\%$ of outside non-family directors & $\begin{array}{c}-1.178 * * * \\
(-9.396)\end{array}$ & $\begin{array}{l}-0.439 * * \\
(-2.026)\end{array}$ & 0.002 \\
\hline$\%$ affiliated directors & $\begin{array}{c}0.604 * * * \\
(4.850)\end{array}$ & & \\
\hline$\%$ affiliated directors ${ }^{2}$ & $\begin{array}{l}-0.012 * * * \\
(-6.445)\end{array}$ & & \\
\hline$\%$ of family ownership at the IPO & $\begin{array}{l}-0.493 * * \\
(-2.099)\end{array}$ & & \\
\hline$\%$ of insider ownership at the IPO & & $\begin{array}{c}0.374 \\
(1.248) \\
\end{array}$ & \\
\hline Underwriter ranking & $\begin{array}{l}-2.799 * * \\
(-2.477)\end{array}$ & $\begin{array}{c}4.676^{* * * *} \\
(2.808)\end{array}$ & 0.002 \\
\hline IPO volume & $\begin{array}{c}0.117 \\
(1.501)\end{array}$ & $\begin{array}{c}-0.402 \\
(-1.283)\end{array}$ & 0.304 \\
\hline Technology dummy & $\begin{array}{l}5.672 * * \\
(2.276)\end{array}$ & $\begin{array}{c}14.236^{* * *} \\
(3.261)\end{array}$ & 0.001 \\
\hline Log of proceeds & $\begin{array}{c}0.429 \\
(0.607)\end{array}$ & $\begin{array}{l}-2.116^{* *} \\
(-2.002)\end{array}$ & 0.077 \\
\hline Firm age & $\begin{array}{l}-1.814 * * * \\
(-4.439)\end{array}$ & $\begin{array}{c}0.924 \\
(1.382)\end{array}$ & 0.027 \\
\hline Cash per sales & $\begin{array}{c}-0.053 * \\
(-1.844) \\
\end{array}$ & $\begin{array}{c}-0.165 \\
(-1.422) \\
\end{array}$ & 0.068 \\
\hline Potential successor dummy & $\begin{array}{c}-2.849 * \\
(-1.966)\end{array}$ & & \\
\hline Year fixed effect & & cluded Inclu & \\
\hline Adjusted $\mathrm{R}^{2}$ & $73.51 \%$ & $21.92 \%$ & \\
\hline
\end{tabular}




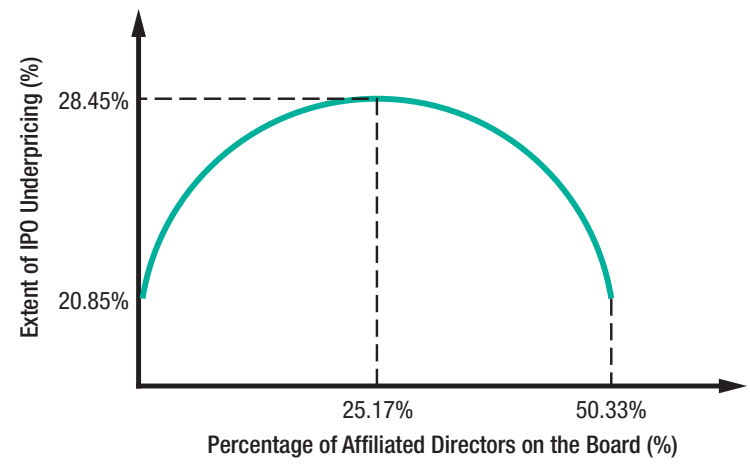

Fig. 1. Extent of IPO underpricing

\section{The moderating effect of industry}

We test Hypothesis 4, which predicts a weaker relationship hypothesized in H1-3 when family firms primarily operate in technology industries by including the interaction term between technology dummy variable and three key independent variables. Such as the percentage of outside directors, the percentage of family ownership at IPO, and underwriter ranking.

Table 4 column 2 the coefficient of the percentage of outside non-family directors is significantly negative at $1 \%$ whereas the percentage outside non-family directors multiplied by technology dummy is significantly positive. The summation of these two coefficients suggests one percent increase in outside non-family directors of technology family firms decreases underpricing by $0.26 \%(1.02-0.76)$, which is significant at $5 \%$ (tstat is 2.105) based on Wald Test. The result supports hypothesis 4 predicting a weaker relationship hypothesized in $\mathrm{H} 1$ for technology family firm IPOs. In column 3, we added the interaction term for non-family firm regression. The percentage of outside directors and its interaction term with technology dummy variable are negatively significant at $5 \%$. Although the increased presence of outside directors reduces underpricing in both tech and non-tech non-family firms, tech firms enjoys more reduction of underpricing. Underwriter ranking for non-family firms has positive relationship with underpricing whereas it has negative relationship with underpricing of family firms.

Column 5 of Table 4 tested hypothesis 4 for the relationship hypothesized in H2. The results show that one percent increase in family ownership at the IPO decreases underpricing by $0.11 \%(0.38-0.27)$ for technology family firm but by $0.38 \%$ for non-tech family firms. The result supports our hypothesis 4 in which the impact of family ownership at the IPO on underpricing is weaker for family firms from technology industries. We performed the same test for non-family firm in column 6 by adding the interaction term of technology dummy and \% of insider ownership. Surprisingly, although insider ownership is not significant, its interaction term with technology dummy is. This indicates that non-family high-tech firms with high percentage of insider ownership are more underpriced. Finally, we compared the impact of underwriter ranking on underpricing between technology and non-tech firms in columns 8 to 10 . 


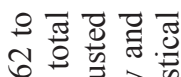
응 政

入 함요

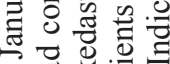

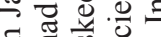
픙 항 $\because$ वे 의 0

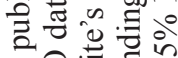

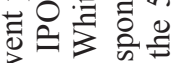
3 का on

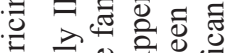

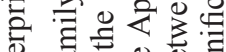

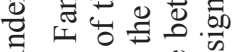
○े

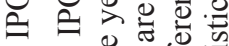

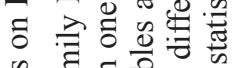

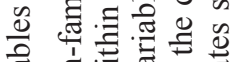
ब 다의

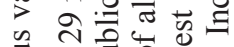

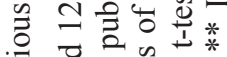
政 壳

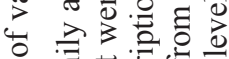
氙 氙 के

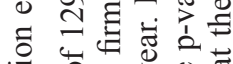
응 00 엥

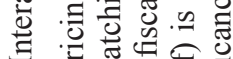

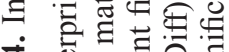
+ च

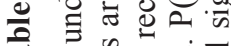
ज 의 응

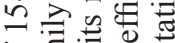

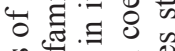
जी 政

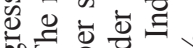
of s

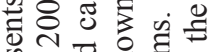

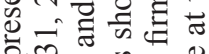

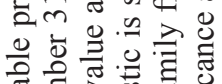

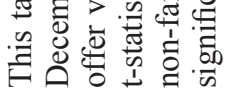

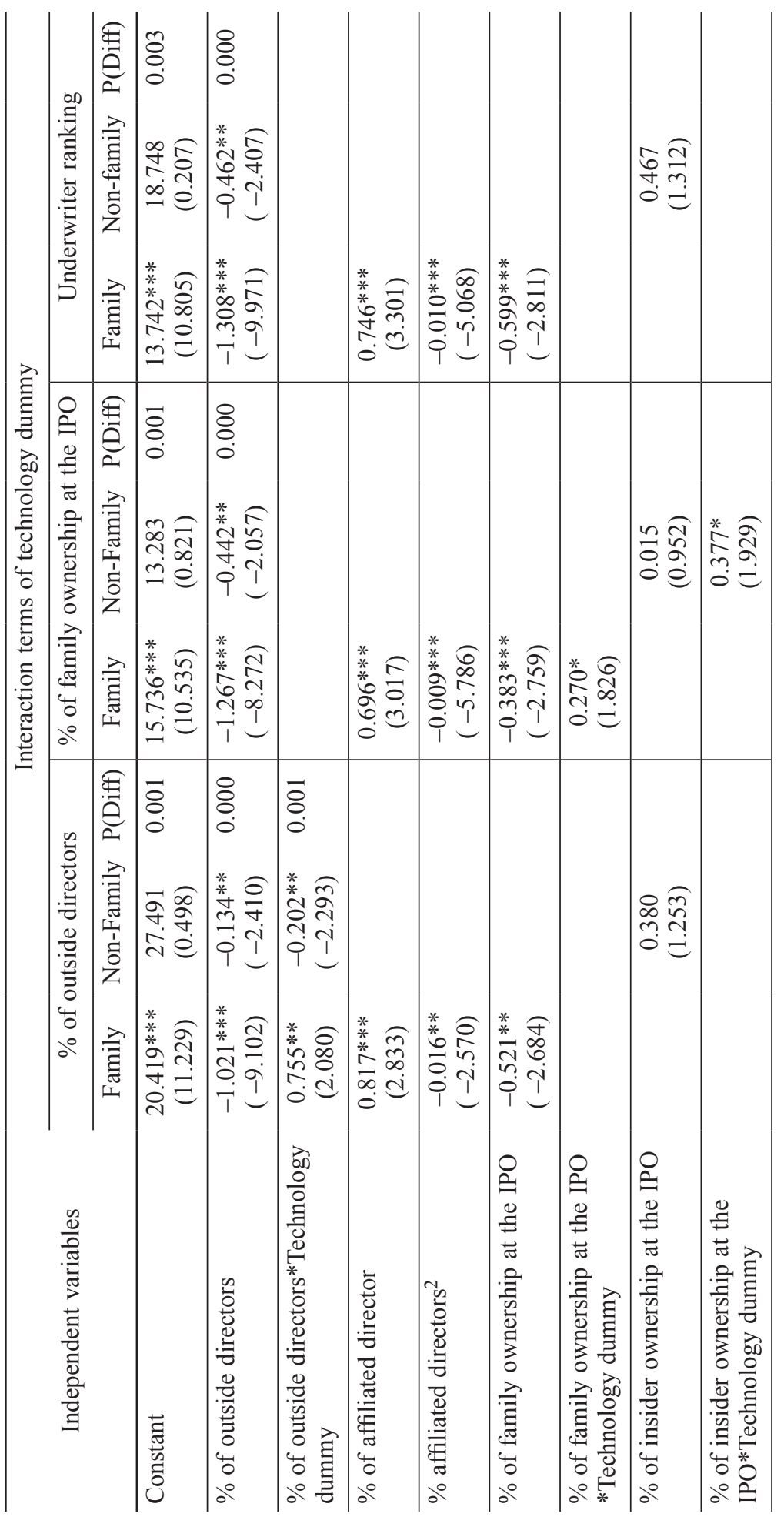




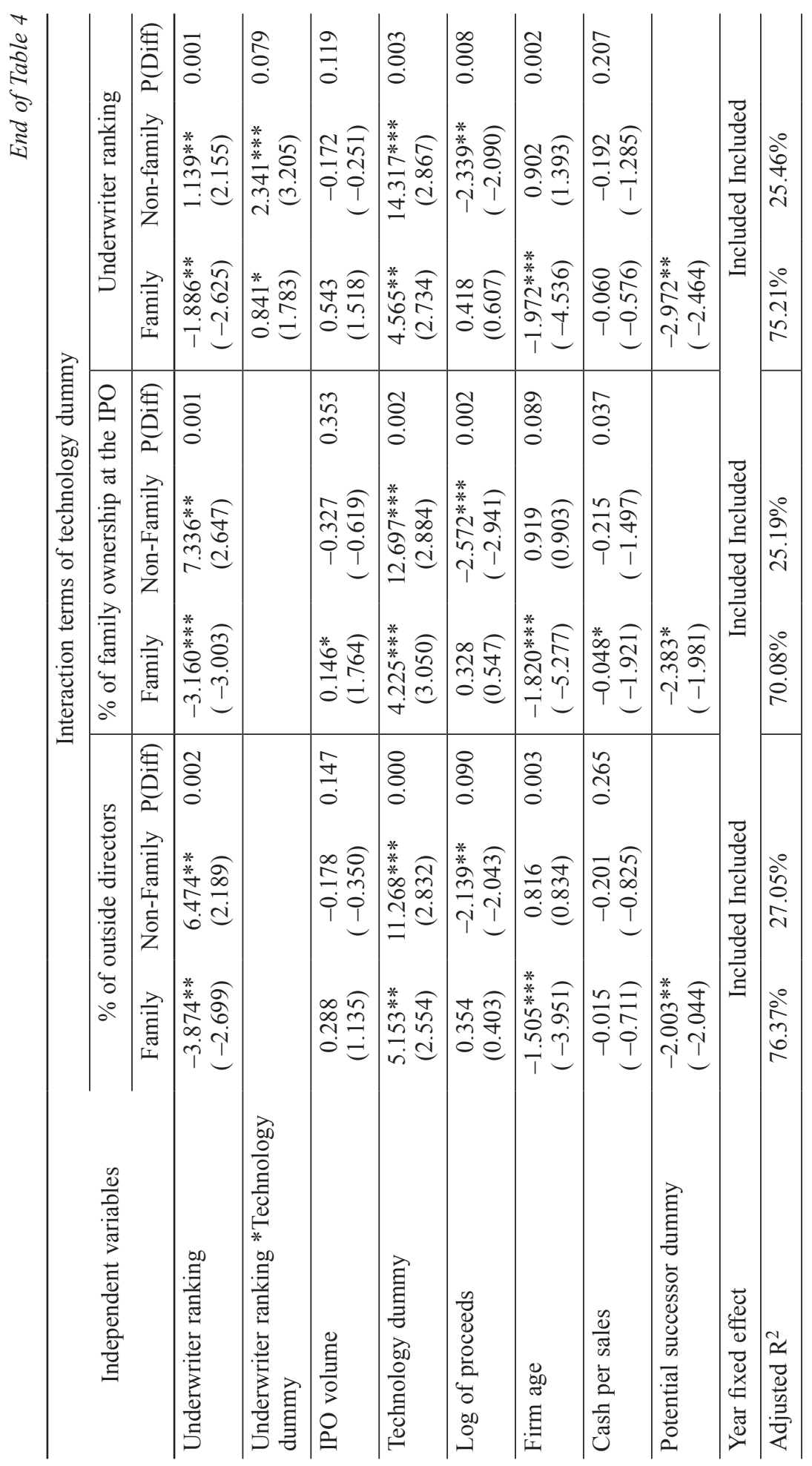


Non-tech family firms benefit more from being associated with prestigious underwriters than tech family firms. The underpricing of non-tech family firms assisted by prestigious investment bankers is reduced by $1.89 \%$ whereas the underpricing of tech family firms assisted by such banks is reduced only by $1.05 \%$. Technology family firms underwritten by prestigious investment banks are able to reduce underpricing; nevertheless, this effect is stronger in non-tech family firms. In contrast to family firms, non-family technology firms associated with high ranked underwriters increase the underpricing by $3.48 \%(1.14 \%+2.34 \%)$ whereas the underpricing increases by $1.14 \%$ for non-tech non-family firms. In sum, the impact of outside directors, family ownership at the IPO, and underwriter ranking on underpricing are weaker when the family firm operates in the technology industries. On the other hand, such impact (of outside directors, insider ownership, and underwriter ranking) is stronger for non-family tech firms. The results support the hypothesis 4 .

\section{Discussion and conclusions}

Signaling help prospective investors of an IPO to better assess the legitimacy of an IPO firm and the value of the IPO. Using data from the Taiwan stock exchange, we examine the relationship between signals, governance and management practices, and IPO performance. The results of our analysis are in agreement with recent studies on the relationship between the corporate governance mechanisms and family business performances (Schulze et al. 2001; Anderson, Reeb 2004; Chan, Li 2008) and the research on the effect of firm legitimacy in equity performances (Certo 2003; Cohen, Dean 2005; Bell, Moore, Al-Shammari 2008). Additionally, several important findings have emerged from our study.

Firstly, there is an interaction between organizational and environmental legitimacies. In this research, the former refers to investor acceptance associated with the governance and management practices of an IPO firm while the latter refers to the industry of operation. Our analysis shows that the appointment of independent directors, underwriter reputation, and post-IPO share retaining improve the monitoring effectiveness of the board and the IPO performance of family firms. Our research also indicates that the non-family, affiliated directors affect the effectiveness of the corporate board by affecting both monitoring and team performance of the board. Previous studies on legitimacy most focus either on the internal factors of investor acceptance (e.g. Certo 2003; Cohen, Dean 2005; Bell, Moore, Al-Shammari 2008) or external factors (e.g. Zuckerman 1999, 2000). The findings reported in this paper link these two schools and suggest a moderation relationship between these two sources of legitimacies.

Secondly, we underscore the role of affiliated directors in the context of family firm IPO. Appointing non-family executives on the board of family business is a very common practice in public family firms and established private family firms. However there is very little empirical evidence about the impact of these individuals on the corporate board and the overall performance of the family firm. While our research only focuses on the context of IPO, it is likely the affiliated directors can have significant impact on governance effectiveness for post-IPO family firms. Future examination of the relation- 
ship between affiliated director appointment and corporate governance may also shed light to resolving the principal-principal agency problem in family firms.

Thirdly, this research proposes a new perspective about the uniqueness of family firms. Although the impact of external environment has been well studied by strategic management and family business researchers, family business literature has been more inclined to focus on intrinsic uniqueness such as how a family firm reacts to external challenges. However it is not unusual that the label of family-owned business invokes distinctive perceptions for external stakeholders (Poza, Alfred, Maheshwari 1997). The results of our analysis show that investors react to IPO signals differently when evaluating family firm IPO deals. It would be helpful for future researchers to identify more sources of such extrinsic uniqueness and the impact of these extrinsic factors on the strategy formulation and implementation of family firms. The results of such research would highlight when and how family and non-family firms adopt different strategies to address competitive challenges. The findings of these studies would also help family firm managers develop effective strategies.

Although our examination of underwriter reputation's impact on IPO performance and the result confirms our prediction, we are surprised by the significant positive correlation between underwriter reputation and the underpricing of non-family firm IPOs. There are two possible explanations. The first one is the asymmetry of bargaining power between prestigious underwriters and issuers. Highly prestigious underwriters have large market shares and are powerful opponents in bargaining. Hiring these high powerful underwriters is likely to cost the IPO firms more than working with a smaller underwriter. Without the benefit of having a prestigious underwriter to neutralize the principal-principal agency problem of family firms, hiring a prestigious underwriter is not likely to give a non-family firm much gain in its IPO. The second explanation is the cost of post-IPO analyst coverage. Recommendations made by star analysts of highly-ranked underwriters give legitimacy and promote a newly listed stock to the market (Zuckerman 1999). As such recommendations facilitate the trading and potentially drive up the trading prices of a new stock. Relatively unknown or young IPO firms are more likely to choose prestigious underwriters to receive stock coverage by star analysts. However, hiring a star analyst of a prestigious underwriter is costly. Underwriters are likely to set a low offer price for IPO equities if their clients request services of their star analysts. This mechanism increases the underpricing of an IPO (Cliff, Denis 2004). Since the average age of non-family firms in this study is about six years younger than the family firms (see Table 1), non-family firms in this study could be more motivated than family firms to request stock coverage by star analysts of their underwriters, thus increases underpricing.

This paper has two major limitations that may suggest possible directions for future research. Firstly, the concept of family has been evolving in the second half of the $20^{\text {th }}$ century. Investors' perception toward family firms in 1962 (the earliest family firm IPO in this study) may not be the same as in the year 2005 (the latest family firm IPO in this study). Future research to track the differences of investor perception toward family firms over time will allow us to differentiate the influence of perceptual differences on the effects of family firm legitimacy and reputation over time. 
Secondly, testing our hypotheses using data collected from one country helps us control the variance in the perceived legitimacy of family firms and institutional factors across countries but the results may not be generalized to other countries with different institutions. Bertrand and Schoar (2006) propose that the relationship between societal family values and economic development is different across economies. In most industrialized economies, the strong family values at the society level are likely to have a negative effect on economic growth, yet such relationship is positive in developing economies. These authors argue that the absence of well-developed financial and legal institutions in the developing economies may have encouraged family involvement in entrepreneurial activities to minimize business risk, while entrepreneurs' families have less contribution to lessen risk associated with institutional environmental uncertainty in developed economies. As the data of this research is collected from one country, we are not able to examine the influence of family values in our central research theme. Future multinational research analyzing the impact of family values could extend and complement the findings from our research.

\section{References}

Anderson, R. C; Duru, A.; Reeb, D. M. 2009. Founders, heirs, and corporate opacity in the United States, Journal of Financial Economics 92(2): 205-222.

http://dx.doi.org/10.1016/j.jfineco.2008.04.006

Anderson, R.; Mansi, S.; Reeb, D. M. 2004. Board characteristics, accounting report integrity, and the cost of debt, Journal of Accounting and Economics 68(2): 263-285.

Anderson, R.; Reeb, D. M. 2003. Founding family ownership and firm performance: evidence from the S\&P 500, Journal of Finance 58: 1301-1328. http://dx.doi.org/10.1111/1540-6261.00567

Anderson, R.; Reeb, D. M. 2004. Board composition: balancing family influence in S\&P 500 firms, Administrative Science Quarterly 49(2): 209-237.

Baker, M.; Gompers, P. A. 2003. The determinants of board structure at the initial public offering, Journal of Law \& Economics 46(2): 569-598. http://dx.doi.org/10.1086/380409

Bathala, C. T.; Rao, R. P. 1995. The determinants of board composition: an agency theory perspective, Managerial and Decision Economics 16(1): 59-69.

http://dx.doi.org/10.1002/mde.4090160108

Beatty, R.; Ritter, J. 1986. Investment banking, reputation, and the underpricing of initial public offerings; Journal of Financial Economics 15: 213-232.

http://dx.doi.org/10.1016/0304-405X(86)90055-3

Bédard, J.; Coulombe, D.; Courteau, L. 2008. Audit committee, underpricing of IPOs, and accuracy of management earnings forecasts, Corporate Governance: An International Review 16(6): 519-535.

Bell, R. G.; Moore, C. B.; Al-Shammari, H. A. 2008. Country of origin and foreign IPO legitimacy: understanding the role of geographic scope and insider ownership, Entrepreneurship Theory \& Practice 32(1): 185-202. http://dx.doi.org/10.1111/j.1540-6520.2007.00221.x

Bertrand, M.; Schoar, A. 2006. The role of family in family firms, Journal of Economic Perspectives 20: 73-96. http://dx.doi.org/10.1257/jep.20.2.73

Bruton, G. D.; Chahine, S.; Filatotchev, I. 2009. Founders, private equity investors, and underpricing in entrepreneurial IPOs, Entrepreneurship Theory and Practice 33(4): 909-928. http://dx.doi.org/10.1111/j.1540-6520.2009.00309.x

Burton, B.; Helliar, C.; Power, D. 2004. The role of corporate governance in the IPO process: a note, Corporate Governance 12(3): 353-360. http://dx.doi.org/10.1111/j.1467-8683.2004.00376.x 
Carter, R.; Manaster, S. 1990. Initial public offerings and underwriter reputation, Journal of Finance 45: 1045-1067. http://dx.doi.org/10.1111/j.1540-6261.1990.tb02426.x

Carter, R.; Dark, F.; Singh, A. 1998. Underwriter reputation, initial returns and long run performance of IPO stocks, Journal of Finance 53: 285-311.

http://dx.doi.org/10.1111/0022-1082.104624

Certo, S. T. 2003. Influencing initial public offering investors with prestige: signaling with board structures, Academy of Management Review 28: 432-446.

Certo, S. T.; Covin, J. G.; Daily, C. M.; Dalton, D. R. 2001. Wealth and the effects of founder management among IPO-stage new ventures, Strategic Management Journal 22: 641-658.

http://dx.doi.org/10.1002/smj.182

Chahine, S.; Tohmé, N. S. 2009. Is CEO duality always negative? An exploration of CEO duality and ownership structure in the Arab IPO context, Corporate Governance: An International Review 17(2): 123-141.

Chan, K. C.; Li, J. 2008. Audit committee and firm value: evidence on outside top executives as expert-independent directors, Corporate Governance: An International Review 16(1): 16-31.

Chiu, S. C.; Sharfman, M. 2011. Legitimacy, visibility, and the antecedents of corporate social performance: an investigation of instrumental perspective, Journal of Management 37(6): 1558-1585. http://dx.doi.org/10.1177/0149206309347958

Clarkson, P. M.; Dontoh, A.; Richardson, G.; Sefcik, S. E. 1991. Retained ownership and the valuation of IPOs: Canadian evidence, Contemporary Accounting Research 8: 115-131.

http://dx.doi.org/10.1111/j.1911-3846.1991.tb00838.x

Cliff, M.; Denis, D. 2004. Do initial public offering firms purchase analyst coverage with underpricing?, Journal of Finance 59: 2871-2901. http://dx.doi.org/10.1111/j.1540-6261.2004.00719.x Coates, J. 2005. Look ahead at 14 technology trends, Research Technology Management 48(5): 7-9.

Cohen, B. D.; Dean, T. J. 2005. Information asymmetry and investor valuation of IPOs: top management team legitimacy as a capital market signal, Strategic Management Journal 26: 683-690. http://dx.doi.org/10.1002/smj.463

Conger, J. A.; Lawler, E. E. 2009. Sharing leadership on corporate boards: a critical requirement for teamwork at the top, Organizational Dynamics 38(3): 183-191.

http://dx.doi.org/10.1016/j.orgdyn.2009.04.007

Daily, C. M.; Certo, S. T.; Dalton, D. R.; Roengpitya, R. 2003. IPO underpricing: a meta-analysis and research synthesis, Entrepreneurship Theory and Practice 27(3): 271-295.

http://dx.doi.org/10.1111/1540-8520.t01-1-00004

DiMaggio, P. 1991. Social structure, institutions and cultural goods: the case of the United States, in P. Bourdieu, J. C. Coleman (Eds.). Social Theory for a Changing Society. Boulder, CO: Westview, 133-155.

Downes, D. H.; Heinkel, R. 1982. Signaling and the valuation of unseasoned new issues, Journal of Finance 37: 1-10. http://dx.doi.org/10.1111/j.1540-6261.1982.tb01091.x

Erven, B. L. 1998. Management succession issues in family businesses, in R. K. Z. Heck (Ed.). The Entrepreneurial Family. Needham, MA: Family Business Resources, Inc.

Esteban, R. B.; Kryssia, M.; Bernardo, R. 2011. Corporate governance and family business performance, Journal of Business Research 64(3): 280-285.

http://dx.doi.org/10.1016/j.jbusres.2009.11.013

Filatotchev, I.; Bishop, K. 2002. Board composition, share ownership, and 'underpricing' of U.K. IPO firms, Strategic Management Journal 23: 941-955. http://dx.doi.org/10.1002/smj.269

Financial Supervisory Commission. 2007. Regulations governing information to be published in public offering and issuance prospectuses [online], [cited 6 June 2008]. Financial Supervisory 
Commission, Executive Yuan, Taiwan. Available from Internet: http://eng.selaw.com.tw/FLAWDAT0201.asp

Fombrun, C.; Shanley, M. 1990. What's in a name? Reputation building and corporate strategy, Academy of Management Journal 33(2): 233-258. http://dx.doi.org/10.2307/256324

Fombrun, C. J.; Gardberg, N. A.; Barnett, M. L. 2000. Opportunity platforms and safety nets: corporate citizenship and reputational risk, Business and Society Review 105(1): 85-106. http://dx.doi.org/10.1111/0045-3609.00066

Gómez-Mejía, L. R.; Haynes, K. T.; Núñez-Nickel, M.; Jacobson, K. J. L.; Moyano-Fuentes, J. 2007. Socioemotional wealth and business risks in family-controlled firms: evidence from Spanish olive oil mills, Administrative Science Quarterly 52(1): 106-137.

Hitt, M. A.; Hoskisson, R. E.; Ireland, D. R. 1990. Mergers and acquisitions and managerial commitment to innovation in M-form firms, Strategic Management Journal 11: 29-47.

Jenkinson, T.; Ljungqvist, A. 2002. Going Public: the Theory and Evidence on How Companies Raise Equity Finance. $2^{\text {nd }}$ ed. New York, NY: Oxford University Press.

Jensen, M. C.; Meckling, W. H. 1976. Theory of the firm: managerial behavior, agency costs and ownership structure, Journal of Financial Economics 3: 305-360.

http://dx.doi.org/10.1016/0304-405X(76)90026-X

Jiang, Y.; Peng, M. 2011. Are family ownership and control in large firms good, bad, or irrelevant?, Asia Pacific Journal of Management 28(1): 15-39.

http://dx.doi.org/10.1007/s10490-010-9228-2

Kim, M.; Ritter, J. 1999. Valuing IPOs, Journal of Financial Economics 53: 409-437. http://dx.doi.org/10.1016/S0304-405X(99)00027-6

Kim, Y.; Cannella, Jr. A. 2008. Toward a social capital theory of director selection, Corporate Governance: An International Review 16(4): 282-293.

Kutner, M.; Nachsheim, C.; Neter, J. 2004. Applied Linear Regression Models. $5^{\text {th }}$ ed. Chicago, IL: McGraw-Hill, Irwin.

La Porta. R.; Lopez-de-Silanes, F.; Shleifer, A.; Vishny, R. 2000. Agency problems and dividend policies around the world, Journal of Finance 55: 1-33.

http://dx.doi.org/10.1111/0022-1082.00199

Lee, P. M. 1997. A comparative analysis of layoff announcements and stock price reactions in the United States and Japan, Strategic Management Journal 18: 879-894.

http://dx.doi.org/10.1002/(SICI)1097-0266(199712)18:11<879::AID-SMJ929>3.0.CO;2-V

Lee, P. M. 2001. What's in a name.com?: The effects of '.com' name changes on stock prices and trading activity, Strategic Management Journal 22: 793-804. http://dx.doi.org/10.1002/smj.177

Leland, H.; Pyle, D. H. 1977. Informational asymmetries, financial structure, and financial intermediation, Journal of Finance 32: 371-387. http://dx.doi.org/10.2307/2326770

Li, L.; Naughton, T. 2007. Going public with good governance: evidence from China, Corporate Governance: An International Review 15(6): 1190-1202.

Litz, R. A. 2008. Two sides of a one-sided phenomenon: conceptualizing the family business and business family as a möbius strip, Family Business Review 21: 217-236.

Loughran, T.; Ritter, J.; Rydqvist, K. 1994. Initial public offerings: international insights, Pacific Basin Finance Journal 2(2-3): 165-199. http://dx.doi.org/10.1016/0927-538X(94)90016-7

Luan, C.-J.; Tang, M.-J. 2007. Where is independent director efficacy?, Corporate Governance: An International Review 15(4): 636-643. http://dx.doi.org/10.1111/j.1467-8683.2007.00593.x

MassMutual American Family Business Survey. 2002. Boston: George G. and Robin Raymond Family Business institute and Massachusetts Mutual Life Insurance Company. 
McDonald, M. L.; Westphal, J. D.; Graebner, M. E. 2008. What do they know? The effects of outside director acquisition experience on firm acquisition performance, Strategic Management Journal 29: 1155-1177. http://dx.doi.org/10.1002/smj.704

Megginson, W.; Weiss, K. 1991. Venture capitalist certification in initial public offerings, Journal of Finance 46: 879-903. http://dx.doi.org/10.1111/j.1540-6261.1991.tb03770.x

Morck, R.; Yeung, B. 2003. Agency problems in large family business groups, Entrepreneurship Theory and Practice 27: 367-382. http://dx.doi.org/10.1111/1540-8520.t01-1-00015

Naldi, L.; Nordqvist, M.; Sjöberg, K.; Wiklund, J. 2007. Entrepreneurial orientation, risk taking, and performance in family firms, Family Business Review 20: 33-47.

http://dx.doi.org/10.1111/j.1741-6248.2007.00082.x

Payne, G. T.; Benson, G. S.; Finegold, D. L. 2009. Corporate board attributes, team effectiveness and financial performance, Journal of Management Studies 46(4): 704-731.

http://dx.doi.org/10.1111/j.1467-6486.2008.00819.x

Pfeffer, J.; Salancik, G. R. 1978. The External Control of Organizations: a Resource Dependence Perspective. New York, NY: Harper \& Row.

Poza, E. J.; Alfred, T.; Maheshwari, A. 1997. Stakeholder perceptions of culture and management practices in family and family firms - a preliminary report, Family Business Review 10: 135-155. http://dx.doi.org/10.1111/j.1741-6248.1997.00135.x

Purnanandam, A.; Swaminathan, B. 2004. Are IPOs really underpriced?, Review of Financial Studies 17: 811-848. http://dx.doi.org/10.1093/rfs/hhg055

Rao, H. 1994. The social construction of reputation: certification contests, legitimization, and the survival of organizations in the American automobile industry 1895-1912, Strategic Management Journal 15: 29-44. http://dx.doi.org/10.1002/smj.4250150904

Rao, R. S.; Chandy, R. K.; Prabhu, J. C. 2008. The fruits of legitimacy: why some new ventures gain more from innovation than others?, Journal of Marketing 72(4): 58-75.

http://dx.doi.org/10.1509/jmkg.72.4.58

Ritter, J. R. 2003. Investment banking and securities issuances, in G. M. Constantinides, M. Harris, R. M. Stulz (Eds.). Handbook of the Economics of Finance. Elsevier, 255-306.

Schulze, W. S.; Lubatkin, M.H.; Dino, R. N.; Buchholtz, A. K. 2001. Agency relationships in family firms: theory and evidence, Organization Science 12(2): 99-116.

http://dx.doi.org/10.1287/orsc.12.2.99.10114

Shekhar, C.; Stapledon, G. 2007. Governance structures of initial public offerings in Australia, Corporate Governance: An International Review 15(6): 1177-1189.

Shapiro, S. P. 1983. Premiums for high-quality products as returns to reputations, Quarterly Journal of Economics 98: 659-681. http://dx.doi.org/10.2307/1881782

Spence, M. 1973. Job market signaling, Quarterly Journal of Economics 87(3): 355-374. http://dx.doi.org/10.2307/1882010

Spence, M. 2002. Signaling in retrospect and the informational structure of markets, American Economic Review 92(3): 434-459. http://dx.doi.org/10.1257/00028280260136200

Srivastava, R. K.; McInish, T. H.; Wood, R. A.; Capraro, A. J. 1997. The value of corporate reputation: evidence from the equity markets, Corporate Reputation Review 1(1/2): 62-68.

Suchman, M. C. 1995. Managing legitimacy: strategic and institutional approaches, Academy of Management Review 20: 571-610.

Sun, L.; Tobin, D. 2005. International listing as a mechanism of commitment to more credible corporate governance practices: the case of the Bank of China (Hong Kong), Corporate Governance: An International Review 13(1): 81-91. http://dx.doi.org/10.1111/j.1467-8683.2005.00405.x 
Villalonga, B.; Amit, R. 2006. How do family ownership, control, and management affect firm value?, Journal of Financial Economics 80: 385-417.

http://dx.doi.org/10.1016/j.jfineco.2004.12.005

Wang, P. 2010. Restructuring to repair legitimacy - a contingency perspective, Corporate Governance: An International Review 18(1): 64-82.

Ward, A. J.; Brown, J. A.; Rodriguez, D. 2009. Governance bundles, firm performance, and the sustainability and complementarity of governance mechanisms, Corporate Governance: An International Review 17(5): 646-660.

Westhead, P.; Howorth, C. 2006. Ownership and management issues associated with family firm performance and company objectives, Family Business Review 19: 301-316.

http://dx.doi.org/10.1111/j.1741-6248.2006.00077.x

Zajac, E. J.; Westphal, J. D. 1994. The costs and benefits of managerial incentives and monitoring in large US corporations: when more is not better, Strategic Management Journal 15: 121-142. http://dx.doi.org/10.1002/smj.4250150909

Zuckerman, E. W. 1999. The categorical imperative: securities analysts and the illegitimacy discount, American Journal of Sociology 104: 1398-1438. http://dx.doi.org/10.1086/210178

Zuckerman, E. W. 2000. Focusing the corporate product: securities analysts and de-diversification, Administrative Science Quarterly 45: 591-619. http://dx.doi.org/10.2307/2667110 


\section{APPENDIX}

\section{Definitions of Pre-IPO Variables}

\begin{tabular}{|c|c|c|}
\hline \multicolumn{3}{|r|}{ Panel A: Independent Variables } \\
\hline Variables & Source & Definition \\
\hline $\begin{array}{l}\% \text { of outside } \\
\text { directors }\end{array}$ & TEJ & $\begin{array}{l}\text { Percentage of number of non-family outside directors by total } \\
\text { number of directors; outside directors are directors, who are not } \\
\text { in the management team. }\end{array}$ \\
\hline $\begin{array}{l}\% \text { of affiliated } \\
\text { directors }\end{array}$ & TEJ & $\begin{array}{l}\text { Percentage of numbers of non-family inside directors by total } \\
\text { number of directors; inside directors are directors, who are in } \\
\text { the management team. }\end{array}$ \\
\hline $\begin{array}{l}\% \text { of family } \\
\text { ownership } \\
\text { at IPO }\end{array}$ & TEJ & $\begin{array}{l}\text { Percentage of total shares owned by members of a family before } \\
\text { the first trading day. }\end{array}$ \\
\hline $\begin{array}{l}\% \text { of insider } \\
\text { ownership } \\
\text { at IPO }\end{array}$ & TEJ & $\begin{array}{l}\text { The percentage of total shares owned by insiders of non-family } \\
\text { IPOs. Insiders include top-five executive officers, directors, and } \\
\text { institutional investors who have beneficial shares ownership of } \\
\text { at least } 5 \% \text {. }\end{array}$ \\
\hline $\begin{array}{l}\text { Underwriter } \\
\text { ranking }\end{array}$ & SDC & $\begin{array}{l}\text { We calculated Loughran and Ritter (2004)'s adjusted Carter- } \\
\text { Manaster underwriter reputation ranking. First, we followed the } \\
\text { approach developed by Carter and Manaster (1990) to rate under- } \\
\text { writer prestige. The Carter and Manaster measure was construct- } \\
\text { ed from the placements of IPO underwriters in the prospectus, } \\
\text { which lists all the investment banking firms that comprise the } \\
\text { underwriting syndicate of an IPO issue with more prestigious } \\
\text { underwriters listed higher. This measure, however, is limited to } \\
\text { U.S. underwriters. Following the idea that more prestigious in- } \\
\text { vestment banks generally underwrite more IPOs, most of which } \\
\text { tend to be larger offerings, we constructed a discrete measure of } \\
\text { underwriter ranking from } 0 \text { (least prestigious) to } 9 \text { (most pres- } \\
\text { tigious) by classifying each lead investment bank for our sample } \\
\text { IPOs into one of } 10 \text { categories according to the global proceeds } \\
\text { of the IPOs the investment bank underwrote during our } 1962- \\
2005 \text { sample period. Specifically, we assign a discrete integer to } \\
\text { each lead underwriter as follows: } 9 \text { if its global proceeds are no } \\
\text { less than } \$ 20 \text { billion; } 8 \text { if global proceeds are between } \$ 10 \text { and } \\
\$ 20 \text { billion; } 7 \text { if global proceeds are between } \$ 5 \text { and } \$ 10 \text { billion; } \\
6 \text { if global proceeds are between } \$ 2 \text { and } \$ 5 \text { billion; } 5 \text { if global } \\
\text { proceeds are between } \$ 1 \text { and } \$ 2 \text { billion; } 4 \text { if global proceeds are } \\
\text { between } \$ 0.5 \text { and } \$ 1 \text { billion; } 3 \text { if global proceeds are between } \\
\$ 0.2 \text { and } \$ 0.5 \text { billion; } 2 \text { if global proceeds are between } \$ 0.1 \text { and } \\
\$ 0.2 \text { billion; } 1 \text { if global proceeds are below } \$ 0.1 \text { billion; and } 0 \text { if } \\
\text { the lead underwriter is not ranked among the top } 500 \text { by the SDC. }\end{array}$ \\
\hline
\end{tabular}

Panel B: Control Variables

\begin{tabular}{lcl}
\hline \multicolumn{1}{c}{ Variables } & Source & \multicolumn{1}{c}{ Definition } \\
\hline $\begin{array}{l}\text { Underpricing } \\
(15 \text { days })(\%)\end{array}$ & $\begin{array}{c}\text { SDC and } \\
\text { Datastream }\end{array}$ & $\begin{array}{l}\text { Cumulative abnormal return from the offering day until fifteenth } \\
\text { day after the IPO adjusted by market return. }\end{array}$ \\
\hline IPO volume & SDC & $\begin{array}{l}\text { The total number of domestic IPOs issued over the 12-month } \\
\text { period ending in the month in which the IPO was issued. }\end{array}$ \\
\hline
\end{tabular}


End of Appendix

\begin{tabular}{|c|c|c|}
\hline Variables & Source & Definition \\
\hline $\begin{array}{l}\text { Technology } \\
\text { dummy }\end{array}$ & $\mathrm{SDC}$ & $\begin{array}{l}\text { It is equal to one if the company belongs to the high and medi- } \\
\text { um-high technology sectors, and zero if it was in the medium- } \\
\text { low and low technology groups. Sectors were grouped according } \\
\text { to the Organization for Economic Co-operation and Development } \\
\text { (OECD) classification of three-digit SIC code according to their } \\
\text { R\&D intensity (Cucculelli, Micucci 2008). }\end{array}$ \\
\hline $\begin{array}{l}\text { Log } \\
\text { of proceeds }\end{array}$ & SDC & $\begin{array}{l}\text { Natural logarithms of the money raised, after fees and expenses } \\
\text { or natural logged shares offered in IPO multiplied by offer price } \\
\text { after fees and expenses. }\end{array}$ \\
\hline Firm age & $\begin{array}{l}\text { SDC and } \\
\text { company's } \\
\text { website }\end{array}$ & $\begin{array}{l}\text { Number of years since the firm was founded before the IPO. } \\
\text { We hand-filled gaps in SDC's coverage of company founding } \\
\text { dates, and manually checked all firms that according to SDC } \\
\text { were zero to three years old at the time of their IPO, because } \\
\text { Loughran and Ritter (2004) note that SDC frequently reports the } \\
\text { most recent incorporation date rather than the founding date. A } \\
\text { detailed discussion of some of the errors in the SDC database can } \\
\text { be found on Alexander Ljungqvist's website at http://pages.stern. } \\
\text { nyu.edu/ aljungqvist.htm. }\end{array}$ \\
\hline $\begin{array}{l}\text { Cash per } \\
\text { sales }\end{array}$ & $\begin{array}{c}\text { SDC and } \\
\text { Worldscope }\end{array}$ & $\begin{array}{l}\text { The amount of cash and equivalents in the most recent fiscal } \\
\text { year before the firm going public divided by sales; all financial } \\
\text { information are annual data. }\end{array}$ \\
\hline $\begin{array}{l}\text { Potential } \\
\text { successor } \\
\text { dummy }\end{array}$ & TEJ & $\begin{array}{l}\text { Coded } 1 \text { if at least one family member from the younger genera- } \\
\text { tion or a founder's sibling is placed in the corporate board or is } \\
\text { a member of top management team. }\end{array}$ \\
\hline
\end{tabular}

Note: TEJ stands for Taiwan Economic Journal.

Hung-bin DING (Dr) is the Associate Professor of Management and International Business in the Sellinger School of Business and Management of Loyola University Maryland. He received his PhD in Management from the Lally School of Management and Technology at Rensselaer Polytechnic Institute. Dr Ding's research interests are in the areas of family business, organization identity, and corporate environmental responsibility. His most recent research has focused on family business IPO, corporate governance in family firms, and corporate sustainability in emerging economies.

Dr Ding has taught strategic management and entrepreneurship courses at the undergraduate, graduate, and executive levels in the U.S. and Taiwan. He has also worked with the government of Taiwan for entrepreneurship policy initiatives. His research has appeared in International Journal of Technology Management, International Journal of Entrepreneurship and Innovation Management, Journal of Business and Entrepreneurship, Issues and Studies, Journal of Enterprising Culture, and Journal of Management and Organization. He has guest edited a special issue of Multinational Business Review on family business in global economy. He also serves on the review board of the Journal of Enterprising Culture and the Journal of Small Business Management.

Kuntara PUKTHUANTHONG's (Dr) main research interests are entrepreneurial finance, valuation, international finance and asset pricing. She received BA in Economics from Chulalongkorn University, Thailand, MBA. in Finance from Washington University, and $\mathrm{PhD}$ in Finance from University of California, Irvine. In the area of Finance, she is specialized in international asset pricing.

Some of her research has been published in the Journal of Financial Economics, Journal of Banking and Finance, Journal of Corporate Finance, Journal of Financial Markets, Financial Review, Economic Note, Pacific Basin Finance Journal, Applied Financial Economics, Financial Analysts Journal, Journal of Investment Management, Journal of Portfolio Management, Global Finance Journal, and Venture Capital Journal.

Dr Pukthuanthong is a Lamfalussy Fellow at the European Central Bank in 2010.

She was also a Professor-in-Residence at Research Affiliates, Newport Beach, CA and now is a senior research consultant at Denali Advisors, La Jolla, CA. 